УДК 159.92: 316.612

Корчакова Наталія

доктор психологічних наук, професор

кафедри вікової та педагогічної психології

Рівненського державного гуманітарного

університету

ORCID iD: 0000-0003-1164-3370

DOI https://doi.org/10.35619/prap_rv.vi13.122

\title{
РЕПУТАЦІЯ ГРУПИ ЯК МОТИВ ДИТЯЧОЇ ПРОСОЦІАЛЬНОСТІ
}

Анотація. Обговорюються питання виникнення $і$ розвитку у дітей стратегічної просочіальної поведінки. Як відомо, просоціальна поведінка ие система переживань $і$ дій спрямованих на Благо іншої людини. Вона має багато різновидів: практична допомога, дарування, справедливий розподіл ресурсу, співчуття $i$ співпереживання, психологічне сприяння, заступництва. Кінцевою метою цих особистісних стратегій $\epsilon$ задоволення потреб Іншого, відповідно до його інтересів, намірів та станів. Все ж гуманістична ідея може здійснюватися людиною на основі різних особистісних спонук. Їх модальність знаходиться у широких межах дихотомічного ряду «альтруїзм - егойзм». Соціально ціннісний вчинок може зумовлюватися певними корисливими ціляям, спрямованими у майбутнє. Одним із таких різновидів сприяння є стратегічна просоиіальна поведінка. Ї̈ диспозиційними основами є три основні спонуки: мотиви рециипроктності, репутації та самопрезентації. Два останні мотиви зумовлені прагненням особистості до отримання сочіального визнання та утвердження власної значущзості.

Репутаційна мотивація просоиіальної поведінки виокремилася у самостійну лінію пізнання нещодавно. У ї̈ аналізі простежуються дві лінії: вивчення впливу на просочіальну поведінку індивідуальної репутацію та вивчення дії репутації групи. Кожен із циих напрямків зосереджений не лише на аналізі зрілих поведінкових форм, а й вивченні онтогенетично ранніх проявів иих тенденцій. У дослідженні аналізуються вікові особливості розуміння $i$ використання дітьми старшого дошкільного віку мотиву репутащії групи у ситуаціях із потенційним просоціальним контекстом. Зазначається, щуо старші дошкільники здатні виконувати систему дій, зорієнтованих на підвищення репутаційного потенціалу групи, та простежувати і контролювати поведінку однолітків з метою покращення результатів діяльності.

Ключові слова: стратегічна просочіальна поведінка, репутація, групова ідентифікація, міжгрупові упередження, інгрупа.

Постановка проблеми. У широкому спектрі психологічної проблематики питанням розвитку просоціальної поведінки у останній період надається особливого значення. Це зумовлено як значущістю феномену, так і рівнем сформованості його теоретичних основ. Просоціальна поведінка - особлива стратегія особистісного самовияву, цільовою та змістовою сутністю якої $є$ сприяння благополуччю Іншого, надання йому допомоги у відповідності із його потребами, емоційними станами, намірами та уподобаннями. Її практичну роль важко переоцінити, оскільки кожна людина зорієнтована на отримання сприяння з боку інших у ситуаціях проблемного характеру. Для кожного із нас значущим $\epsilon$ не лише пряме сприяння, а й усвідомлення готовності інших прийти на допомогу. Просоціальна поведінка - основа гуманістично зорієнтованої взаємодії та кооперації між людьми. Ії віковий генезис є віддзеркаленням процесів морального зростання особистості, розгортання механізмів іiі соціалізації.

Розкриття психологічної сутності явища неминуче пов'язане із вивченням його мотиваційних основ. Що спонукає людину вести себе просоціально, які рушійні сили спричиняють емпатійні переживання чи надання практичної підтримки, дарування 
матеріальних ресурсів, чи прагнення до справедливого розподілу? Ці та інші питання широко дискутуються у психологічній науці. При розкритті мотиваційних основ просоціальної поведінки нам найбільш імпонує підхід Бетсона, згідно якого у спонукальній системі просоціального феномену виокремлюється чотири групи мотивів: альтруїзм, колективізм, егоїзм, принциповість (Герріг, 2004, с. 900). Їх розміщення на континуумі «інтереси Іншого - власні потреби» засвідчує, що значна кількість просоціальних самовиявів пов'язана з реалізацією егоїстичної мотивацій.

Аналіз останніх досліджень 3 проблеми. У загальній сукупності егоїстичних устремлінь можна виокремити дві групи спонук: ідеї позитивної реципрокності (Аронсон, 2002) та турбота про власне «соціальне Я» (Ковальова, 2016; Мазур, 2008; Чалдіні, 2002; Izuma et al., 2011; Haley \& Fessler, 2005; Ariely et al., 2009; Lamba \& Mace, 2010).

Не зупиняючись на мотивах позитивної реципрокності зазначимо, що у багатьох вітчизняних і зарубіжних дослідженнях наголошується, що усвідомлення людиною власної цінності стимулює зростання іiї готовності до просоціальної допомоги. Турбота про особисту репутацію є сильним поведінковим стимулом як в індустріальних, так і в традиційних суспільствах (Fehr, 2004. с. 449-450). Як стверджує Ковальова (2016), простежується взаємозв'язок між виразністю компонентів самоставлення та мотивами надання сприяння. Чим більш привабливим $є$ образ «Я», тим відвертіше говорить респондент про свою готовність надавати допомогу і тим частіше надає iї із альтруїстичних міркувань. На думку Мазур (2008), модель просоціальної поведінки передбачає наявність позитивних уявлень особистості про себе, пов'язаних із здатністю до солідарності і співчуття; систему життєвих цінностей, які визначають стратегії взаємодії зі світом та здатність особистості реалізовувати себе на шляху альтруїстичної, суспільно значимої діяльності. Якщо у моделі американських психологів Венцель, Уайтхоус (Wentzel, Whitehous, 2007) увага акцентується насамперед на ціннісно-мотиваційній сфері особистості, то у роботі Мазур (2008) на одну із перших позицій піднімається конструкт самосвідомості.

Дещо інші аспекти взаємозв'язку ставлення до себе та мотиву допомоги обговорюються у роботі Чалдіні, Кенрік, Нейберг (2002). На думку цих психологів, спонукальною силою просоціальних вчинків $\epsilon$ не лише позитивна самооцінка, а й бажання підтримати, зберегти свій образ «Я». Просоціальна поведінка, як і будь-яка інша осмислена дія, впливає на уявлення людини про себе, а отже, можемо використовувати для підвищення або підтвердження репутації (с. 132). Отже, прагнення підтримувати позитивну особисту репутацію визнається у психологічній науці як одна із дієвих спонук просоціальної активності. Вікові аспекти репутаційної мотивації просоціальної поведінки аналізуються в роботах Леймгрубер та ін. (Leimgruber, Shaw, Santos, \& Olson, 2012); Енгельман та ін. (Engelmann, Herrmann, \& Tomasello, 2012); Келсі та ін. (Kelsey, Grossmann, Amrisha, 2018). Зокрема у цих дослідженнях встановлено, що починаючи з п'яти років діти можуть керувати своєю репутацією. Їх дії розподілу набувають вищого рівня просоціальності за умови усвідомлення можливості зовнішнього контролю чи спостереження зі сторони партнерів. При цьому у експериментальних ситуаціях «спостерігаючих очей» навіть 3-річні діти схильні до репутаційних самоспостережень та зміни своєї активності (Kelsey, Grossmann, Amrisha, 2018). У роботі Шоу та ін. діагностовано схильність 6-річних дітей діяти у логіці завуальованої справедливості. Демонструючи розподільчу щедрість, діти у той же час, вдаються до обману, прагнучи у такий спосіб одержати більшу особистісну вигоду (Shaw, Montinari, Piovesan, Olson, Gino, \& Norton, 2014). На думку вчених, зміни у просоціальній активності дітей дошкільного віку вказують на мимовільне управління репутаційною мотивацією. Пояснюючи це припущення Томазелло та його колеги наголошують, що така поведінка корисна для налагодженню співпраці та побудови дружніх стосунків. Діти, які більш щедро діляться і менше обманюють чи крадуть, у ситуаціях, коли за ними спостерігають партнери, вірогідніше будуть обрані однолітками для подальшої гри (Tomasello, Vaish, 2013).

Поряд із цим, у науковій літературі обговорюються ідеї свідомого застосування дітьми стратегії управління репутацією. Увага у цьому контексті перш за все, зосереджується 
на використанні дітьми самопрезентаційної мотивації. За даними Аронсона (2002) самопрезентація є більш чітко спланованою стратегічною поведінкою, яка зорієнтована на керування враженнями, з метою отримання певної вигоди. Серед досліджень, присвячених аналізу репутаційної мотивації, на особливу увагу заслуговують роботи, що охоплюють не лише достатньо широкий віковий діапазон, а й зорієнтовані на простеження генези прихованої та відкритої репутаційної стратегії. Однією із досліджень такого спрямування $\epsilon$ робота Ейлід Кейдж із Лондоського університету (Сage, 2015). У iï дослідженні простежується динаміка і особливості репутаційних самовиявів у період із 6 до 14 років. Як i у більшості робіт, спрямованих на вивчення репутаційної мотивації у контексті просоціальної поведінки, у цьому дослідженні використовуються експериментальні ситуації на обмін матеріальним ресурсом у приватній та публічній ситуаціях. Гіпотезою дослідження стало уявлення про те, що при наявності репутаційних схильностей діти виявлятимуть більшу щедрість за умови наявності зовнішніх спостерігачів. При цьому увага зосереджувалася на вивченні двох типів репутаційної поведінки: автоматичної та навмисної. Для диференціації цих типів поведінки дітям пропонувалося відповісти на питання щодо бажаності-небажаності, розкриття їх нещедрої поведінки перед однолітками. На основі попередніх досліджень прогнозувалося, що на відміну від автоматичної репутаційної поведінки, яка з'являється до кінця 6 років, більш обдумана явна форма керування репутацією, повинна з'явитися до середини молодшого шкільного віку (Cage, 2015, с. 112). Все ж отримані результати не підтвердили ідеї ранньої появи прихованого керування репутаційними враженнями. Автор робить висновок, що здібності до автоматичне керування репутацією є достатньо витонченою навичкою, яка започатковується в підлітковому віці і поступово автоматизується в дорослий період життя. Підлітковий вік пов'язаний 3 загостреною чутливістю підлітків до думок інших щодо своєї самості (Cage, 2015, с. 126). Що ж до розвитку відкритого репутаційного керування автор доходить висновку, що його вікова генеза має U-подібну траєкторію з дією різних механізмів у різні вікові періоди. Свідоме керування репутацією з'являється близько 8 років, набуваючи з віком селективності та витонченості (Cage, 2015, с. 112). Серед основних механізмів, що стимулюють репутаційну стратегію автор виокремлює чотири : теорію розуму, соціальну мотивацію, очікування взаємності та стримуючий контроль.

Отже, аналіз теоретичних джерел засвідчує, що вивчення вікової генези стратегічної просоціальності започатковано порівняно недавно і у цьому питанні існують суперечливі точки зору та дискусійні питання.

Метою цього повідомлення є поглиблення наукової інформації з питань розвитку просоціальної мотивації репутаційного спрямування у дитячому віці, через виокремлення впливу механізму групової ідентифікації.

Виклад основного матеріалу дослідження. Виконані нами спостереження взаємодії дітей у групах дітей дошкільного віку дозволяють стверджувати, що навіть у цьому віковому періоді дія механізмів групової диференціації та групової репутації уже чітко представлені. Це виявляється як у життєдіяльності постійних дитячих спільнот, так i у процесі функціонування тимчасових ігрових об'єднань. Наведемо приклад:

Розділившись на дві колонки діти грають в естафетну гру. Основне завдання перемогти суперників. При иьому кожному учаснику по-черзі необхідно передавати м'яч членам своєї підгрупи та змінювати своє місие у колоні. Діти увійшли в азарт. Вони підстрибують, кричать, голосно підбадьорюють кожного з учасників своєї команди. Іринка отримала м'яча, але не втримала його і він далеко відкотився від гравиів. Час був втрачений і ї̈ команда програла. До дівчинки підбіг хлопчик із ї̈ команди. Стиснувши кулаки, він гнівно закричав: «Це через тебе ми програли! (На його обличчя промайнула $i$ заздрість до переможчів, і злість на дівчинку і образа за свою групу). Тікай звідси!!! Як дам зараз!!! Більше не будемо грати з тобою!!!».

Незважаючи на досить різку поведінку хлопия ніхто з однолітків не став на захист дівчинки. 
Як видно з наведеного прикладу, ідея «Ми» і «Вони» чітко представлена у дитячій свідомості. Вона стала причиною як агресивної поведінки одного із учасників гри, так i викликала розчарування, невдоволення та беземпатійність інших. Чи може група та іiі репутація стимулювати позитивні особистісні стратегії, чи здатна вона вплинути на просоціальну поведінку іi членів? Чи здатні діти здійснювати вклад у формування позитивної репутації групи. На це питання і покликане пролити світло це повідомлення.

Входження дітей у формальні і неформальні спільноти зумовлює включення механізмів приєднання. Стилізований та міжособистісний способи соціалізації (через вікову субкультуру та значущих інших) забезпечують дитині ідентифікацію себе з групою, що позначається на різних аспектах іï поведінки (Мудрик, 2011, с. 69). Через членство у спільнотах дитина набуває первинний соціальний досвід, вправляється у реалізації засвоєних норм і правил, набуває ознак первинної ідентичності. При цьому інгрупові впливи об'єднують у собі два начала: виокремлення спільних ознак членів спільноти, і відповідно формування групової ідентичності, та протиставлення групи іншим об'єднанням, через виокремлення й порівняння.

До недавнього часу вибірковість у ставленні дітей до своєї групи пов'язували переважно із явищем фаворитизму. Все ж останні дослідження німецьких вчених засвідчують, що протистояння з іншими спільнотами також може виступати детермінуючим чинником. На думку Девіда Буттельмана та Роберта Бьома цей негуманний тип мотивації започатковує своє функціонування із сьомого року життя (Buttelmann, Böhm, 2014). Почуття антипатії, недружелюбності та ворогування у наступні вікові періоди є достатньо потужними мотиваційними джерелами поведінки дітей у групі, послаблюючи їх просоціальну поведінку щодо інших людей чи спільнот.

Питання вивчення впливу групової репутаційної мотивації на просоціальну поведінку дітей виокремилися у науковому просторі лише у останні роки. Як зазначає німецький вчений Енгельманн досліджень цього спрямування небагато (Engelmann, Herrmann \& Tomasello, (2012)). Робота науковців із Інституту еволюції Макса Планка показала, що навіть діти п'ятирічного віку виявляють схильність до піклування про репутації своєї групи і ці прагнення позитивно впливають на рівень дитячої просоціальності. В умовах, коли репутація групи була поставлена на карту, діти виявили схильність здійснювати інвестування в репутацію своєї групи, вибірково збільшуючи розмір особистого внеску. Цей тип поведінки у процесі розподілу ресурсу спостерігався навіть тоді, коли їхні індивідуальні внески були анонімними (тобто просоціальні вчинки не могли співвідноситися з поведінкою окремо взятої дитини). Все ж публічність просоціальних самовиявів є більш дієвим мотиватором, коли 5-річні дошкільники діють в межах створеної групи, а їх пожертви є публічними. За цих умов вони ділилися більшою кількістю іграшок з однолітками із іншого дитячого садка, ніж тоді коли ресурсний поділ був здійснений у приватних умовах. Нинішні дослідження Енгельманн та його колег свідчать, що турбота про репутацію групи відрізняється від турботи про репутацію особистості, і $\epsilon$ відносно незалежним механізмом (Engelmann, Herrmann \& Tomasello, 2018; Engelmann, Over, Herrmann \& Tomasello, 2013; Engelmann, Rapp, 2018). У дослідженні зазначається, що незважаючи на те, що експериментальні групи дітей були невеликими за розміром (мікрогрупи з 3 чоловік) отримані результати можуть частково переноситися і на розуміння процесів у більших групах, хоча збільшення кількості учасників певною мірою дозволяє перекладати просоціальні вклади на плечі інших партнерів по спільноті. Репутаційна поведінка особливо загострюється, коли відсутня можливість продемонструвати індивідуальний репутаційний потенціал. Останні результати засвідчують, що дитячі просоціальні дії можуть бути викликані більше занепокоєнням щодо репутації, ніж утвердженням принципу справедливості.

Близькі за змістом є і результати, отримані при вивченні схильності старших дошкільників до міжгрупових упереджень. Відразу зазначимо, що на сьогодні це досить дискусійна тема, оскільки незначні зміни у моделях експериментальних ситуацій, використаних у різних дослідженнях, породжують суттєві, а іноді і кардинально відмінності отриманих результатах. Для нашого дослідження найбільш цікавими є роботи у яких вдалося 
простежити ознаки групового фаворитизму у дітей. Ярроу Данхем, Ендрю Скотт Барон та Сьюзан Кері вивчалися питання схильності дітей до міжгрупових упереджень (Dunham, Baron, Carey, 2018). За результатами проведених експериментів було встановлено, що включення дітей у експериментальні мікрогрупи здатне спричинити широкого спектру міжгрупових упереджень навіть у 5-річних дітей.

Рушійною силою мінімального групового ефекту є загальна афективна позитивність. Як зазначають Данхем та його колеги, незважаючи на відсутність у дітей інформації щодо відносного статусу груп чи будь-якого іншого конкурентного контексту, дошкільники демонстрували схильність до приписування переваг власній групі через поведінкові атрибуції, очікування більшої взаємності у процесі розподілу ресурсу, спотворення вхідної інформацію про членів мікрогрупи через вибіркове сприйняття інформації (наданням переваги позитивному контексту). Дослідження виконувалося у логіці групової парадигми функціонування мінімальних експериментальних груп, запропонованої Анрі Тешфелом (Tajfel), згідно якої в учасників групи не має жодних підстав надавати перевагу своєму об'єднанню. Попередні дослідження (Otten \& Wentura, 1999) та мета аналітичні огляди (Mullen, Brown, \& Smith, 1992) підтвердили, що ефекти експериментальної мікрогрупи провокують виникнення міжгрупових упереджень, причиною яких може виступати як соціальне научіння, так і дитячі когнітивні обмеження. Як показали дослідження Данхем міжгрупові упередження у дітей дошкільного віку виникають досить швидко, мають достатньо потужний ефект і не потребують жодної підтримуючої соціальної інформації. Діти вважають, що члени інгрупи мають більші шанси виконати добрі дії. Дослідники припускають, що більш швидке кодування позитивних дій, що виконуються членами інгрупи, у подальшому здатне трансформувати іiї сприйняття (Dunham, Baron, Carey, 2018). Таким чином, дослідження по вивченню вікових аспектів групових упереджень ще не дають відповіді на питання виникнення i функціонування стратегічної репутаційної просоціальності, та все ж вони розкривають важливі механізми цього процесу - автоматичне перенесення на спільноту позитивного самосприйняття та прагнення здійснювати самоутверджуватися у такий спосіб. Групові ефекти мікрогрупи є детермінуючою силою як формування соціальних упереджень, так і розвитку репутаційних форм просоціальності. Цікаві дослідження щодо відмінностей у просоціальній поведінці дітей щодо членів своєї групи отримані також ізраїльським вченими Дізендрук та його асистентом Бенозіо (Desenzruck, Benozio (2015).

Отже, групова репутація - це динамічна характеристика, яка формується протягом достатньо тривалого часу. Репутація є цінним надбання групи. Сформована репутація здатна підвищити кооперацію у дитячих спільнотах, схильність дітей до співпраці і взаємодії. Репутаційна просоціальна мотивація належить до стратегічних особистісних стратегій. Боротьба за групову репутацію включає три лінї активності дітей: посилення репутаційних показників шляхом підвищення власного вкладу, стимулювання дій інших учасників групи, боротьба із плітками.

Прочедура дослідження. Для аналізу розуміння і використання дітьми мотиву групової репутації та їі впливу на просоціальну активність дітям було запропоновано взяти участь у конкурсі «Художники». Мета конкурсу - прикрасити малюнками групову кімнату дітей молодшої групи. Участь у конкурсі беруть дві підгрупи учасників. Обов'язковою умовою конкурсу є якісне виконання робіт усіма учасниками підгрупи. Перемагає підгрупа, яка буде визнана «групою художників». До початку експерименту проводилося спостереження за дітьми під час занять із малювання. Їх основною метою було виокремлення показників, що засвідчують наявність уваги дітей до партнерів та їх діяльності. Усі прояви дитячої уваги були віднесені нами до трьох категорій: дії споглядання (припинення дитиною власної діяльності для спостереження за партнером); вербальні вказівки чи судження, щодо роботи товаришів; прямі дії допомоги чи втручання. Кожна із виокремлених поведінкових ліній оцінювалася за семибальною шкалою та враховувалася при визначення інтегрального показника активності. У подальшому саме ці показники враховувалися при аналізі репутаційної активності дітей. 
Перейдемо до обговорення результатів. Спостереження за процесом малювання дітьми в умовах навчальних занять показало, що після отримання завдання i його обговорення дошкільники заглиблюються у зображувальну діяльність, не проявляючи особливої уваги до роботи партнера. Елементи спостережень за роботою інших виникали епізодично і не були характерними для більшості учасників. При цьому дії споглядання стосувалися не скільки процесу виконання завдань, скільки отриманого результату. Простежувалися дії співставлення власних малюнків із роботами партнерів. Низькою була i вербальна активність дітей щодо діяльності інших учасників. Окремі звертання стосувалися ідей планування роботи іншою дитиною чи уточнення сюжету. При цьому розмови велися без відриву від малювання. Поради щодо малюнків чи вказівки на їх покращення дітьми практично не висловлювалися.

Аналіз засвідчив, що серед трьох виокремлених показників, які б свідчили про наявність уваги дітей до діяльності партнерів, наймеш представленою виявилася група прямих дій сприяння. Лише у окремих випадках спостерігалися дії інструментальної допомоги: передавання необхідних предметів, піднімання предметів, що впали. У цілому спостереження показали, що творча робота 3 малювання сприймаються дітьми як індивідуальне завдання. Відповідно це позначається на процесі його виконання. Лише на початковому та завершальному етапі діти проявляли увагу до діяльності інших учасників процесу та їх результатів. В умовах виконання конкурсного завдання ситуація змінилася. Наймеш яскраві зміни простежувалися у поведінці дітей за критерієм споглядання. Хоча i тут спостерігалося певне підвищення уваги до роботи партнерів. Найбільш яскраві зміни були зафіксовані нами критерієм вербального супроводу процесу малювання. Кількість висловлювань у ситуації експерименту зросла більше ніж у двічі (від 2,3 балів до 5,4 балів) (див. рис. 1.). У їх змісті прозвучали ідеї: стимулювання («старайся», «давай швидше»), критичних вказівок члена своєї групи («акуратніше малюй», «ну, що це у тебе?», «хто ж так малює?»); упередженні оцінки щодо можливостей учасників другої групи «у них не вийде», «понамазують», «які ж вони художники?».

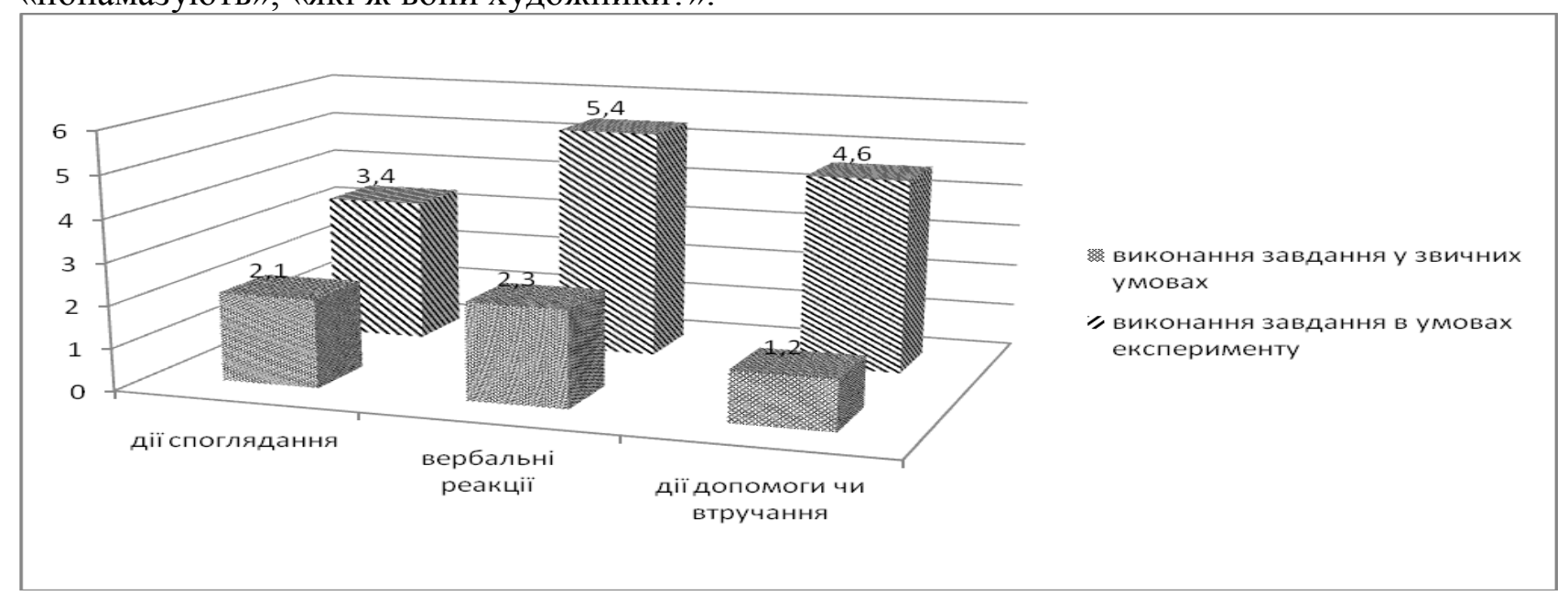

\section{Рис. 1 Кількісні показники різних типів прояву уваги дітей до виконання завдань дітьми із іншої групи}

Для нас найбільш цікавими були висловлювання, спрямовані на утвердження репутаційного потенціалу групи («у нас завжди краще виходить», «ми молодці») та іiі просоціальності («у малишні буде красиво, бо ми стараємося», «діти зрадіють подарунку»). У цих висловлюваннях простежується не лише прагнення дітей надавати певні преференції членам своєї групи, а й спроби утверджувати іiі статус та демонструвати iї переваги. При виконанні завдань в експериментальних умовах змінився і стиль дитячої поведінки та їх висловлювань. Діти говорили емоційніше, голосніше, вели себе більш розкуто та шумно.

Прагнучи отримати для своєї групи визнання, діти вдалися до використання стратегій взаємодопомоги у своїх підгрупах. Хтось підправляв малюнок товариша, хтось допомагав 
виконувати його швидше. Зазначимо, що не всі допомагаючи дії були вдалими та адекватно сприйнятими партнерами. Все ж вони засвідчили підвищення просоціальної активності в умовах конкурентної взаємодії та наявності репутаційної мотивації.

Висновки і перспективи подальших розвідок. Сукупність доказів свідчить про те, що просоціальна поведінка, така як співпраця, підтримка та допомога $є$ показником соціальної компетентності дітей та їх морального розвитку. Вона виступає важливою умовою налагодження позитивних стосунків у дитячих спільнотах. Ї̈̈ мотиваційні джерела мають широкий спектр представлення: від глибокої стурбованості за благополуччя іншої людини, до реалізації власних намірів. Репутаційна мотивація зумовлена процесами самоутвердження. Її реалізація можлива не лише у формі побудови особистісної, а й групової репутації. Розуміння репутаційної мотивації та перші спроби іiі використання, як особистісної стратегії у ситуаціях із потенційним просоціальним контекстом, викристалізовуються до кінця дошкільного періоду. Простеження вікової генези когнітивної та поведінкової складової цього типу мотивації належить до перспективних ліній психологічного аналізу просоціальної поведінки особистості.

\section{СПИСОК ПОСИЛАНЬ}

Аронсон, Э. (2002). Социальная психология. Психологические законы поведения человека в сочиуме. Санкт-Петербург: Прайм-ЕВРОЗНАК.

Герриг, Р. (2004). Психология и жизнь (16-е изд.). Санкт-Петербург: Питер.

Ковальова, Ю.В. (2016). Особенности просоциального поведения студентов азербайджанського, белорусского и русского этносов во взаимосвязи с индивидуальными иенностями. (Дис. канд. психол. наук). Смоленск.

Мазур, Ю. О. (2008). Сочиально-психологический тренинг личностного роста как средство развития просоциального поведения. (Дис. канд. психол. наук). Ярославль.

Мудрик, А. В. (2011). Социализация человека (3-е изд.). Москва: Издательство Московского психолого-социального института.

Чалдини, Р. (2002). Социальная психология. Пойми других, чтобы понять себя! Агрессия. Санкт-Петербург: Прайм-ЕВРОЗНАК.

Buttelmann, D., \& Böhm R. (2014). The ontogeny of the motivation that underlies in-group bias. Psychol Sci, 25(4), 921-927. Retrieved from doi: 10.1177/0956797613516802.

Cage, E. A. (2015). Mechanisms of social influence : reputation management in typical and autistic individuals. (Doctoral thesis). UCL Institute of Education. University of London.

Dunham, Y, Baron, A. S., \& Carey, S. (2018). Consequences of "minimal" group affiliations in children. Child Develop. 2011, 82 (3), 793-811.

Engelmann, J. M., Herrmann, E., \& Tomasello, M. (2012). Five-year olds, but not chimpanzees, attempt to manage their reputations. PLOS ONE, 7. Retrieved from http://dx.doi.org/10.1371/journal.pone.0048433.

Engelmann, J. M., Over, H., Herrmann, E., \& Tomasello, M. (2013). Young children care more about their reputation with ingroup members and potential reciprocators. Developmental Science, 16, 952-958.

Engelmann, J. M., Herrmann, E., \& Tomasello, M. (2018). Concern for Group Reputation Increases Prosociality in Young Children. Psychological Science. 29 (2), 181-190. Retrieved from https://journals.sagepub.com/doi/abs/10.1177/ 0956797617733830.

Engelmann, J. M., \& Rapp, D. J. (2018). The influence of reputational concerns on children's prosociality. Current Opinion in Psychology. 20, 92-95. Retrieved from http://dx.doi.org/10.1016/j.copsyc.2017.08.024.

Fehr, E. (2004). Human behaviour: don't lose your reputation. Nature, 432, 449-450.

Kelsey, C., Grossmann, T., \& Amrisha, V. (2018). Early Reputation Management: Three-Year-Old Children Are More Generous Following Exposure to Eyes Front Psychol, 9, 698. Retrieved from doi: 10.3389/fpsyg.2018.00698. 
Leimgruber, K. L., Shaw, A., Santos, L. R., \& Olson, K. R. (2012). Young Children Are More Generous when Others Are Aware of Their Actions. PLoS ONE, 7 (10).

Shaw, A., Montinari, N., Piovesan, M., Olson, K. R., Gino, F., \& Norton, M. I. (2014). Children develop a veil of fairness. Journal of Experimental Psychology: General, 143, 363-375. Retrieved from http://dx.doi.org/10.1037/ a0031247.

Tomasello, M., \& Vaish, A. (2013). Origins of human cooperation and morality. Rev. Psychol., 64, 231-255.

Wentzel, K. R., Filisetti, L., \& Looney, L. (2007). Adolescent prosocial behavior: The role of selfprocesses and contextual cues. Child. Develop, 78 (3), 895-910.

Whitehous, H., Jong, J., \& Buhrmester, M. D. (2017). The evolution of extreme cooperation via shared dysphoric experiences Sci. Rep. 7. Retrieved from https://www.ncbi.nlm.nih.gov/pmc/articles/PMC5349572/.

\section{REFERENCES}

Aronson, E. (2002). Sotsialnaya psikhologiya. Psikhologicheskiye zakony povedeniya cheloveka $v$ sotsiume [Social Psychology. The psychological laws of human behavior in society]. SanktPeterburg: Praym-EVROZNAK. [in Russian].

Gerrig, R. (2004). Psikhologiya i zhizn [Psychology and life] (16-e izd.). Sankt-Peterburg: Piter. [in Russian].

Kovalova, Yu. V. (2016). Osobennosti prosotsialnogo povedeniya studentov azerbaydzhanskogo. belorusskogo i russkogo etnosov vo vzaimosvyazi s individualnymi tsennostyami [Features of prosocial behavior of students of Azerbaijani, Belarusian and Russian ethnic groups in conjunction with individual values]. (Dis. kand. psikhol. nauk). Smolensk. [in Russian].

Mazur, Yu. O. (2008). Sotsialno-psikhologicheskiy trening lichnostnogo rosta kak sredstvo razvitiya prosotsialnogo povedeniya [Socio-psychological training of personal growth as a means of developing prosocial behavior]. (Dis. kand. psikhol. nauk). Yaroslavl. [in Russian].

Mudrik, A. V. (2011). Sotsializatsiya cheloveka [Socialization of man] (3-e izd.). Moskva: Izdatelstvo Moskovskogo psikhologo-sotsialnogo instituta. [in Russian].

Chaldini, R. (2002). Sotsialnaya psikhologiya. Poymi drugikh. chtoby ponyat sebya! Agressiya [Social Psychology. Understand others to understand yourself! Aggression]. SanktPeterburg: Praym-EVROZNAK. [in Russian].

Buttelmann, D., \& Böhm R. (2014). The ontogeny of the motivation that underlies in-group bias. Psychol Sci, 25(4), 921-927. Retrieved from doi: 10.1177/0956797613516802. [in English].

Cage, E. A. (2015). Mechanisms of social influence : reputation management in typical and autistic individuals. (Doctoral thesis). UCL Institute of Education. University of London. [in English].

Dunham, Y, Baron, A. S., \& Carey, S. (2018). Consequences of "minimal" group affiliations in children. Child Develop. 2011, 82 (3), 793-811. [in English].

Engelmann, J. M., Herrmann, E., \& Tomasello, M. (2012). Five-year olds, but not chimpanzees, attempt to manage their reputations. PLOS ONE, 7. Retrieved from http://dx.doi.org/10.1371/journal.pone.0048433. [in English].

Engelmann, J. M., Over, H., Herrmann, E., \& Tomasello, M. (2013). Young children care more about their reputation with ingroup members and potential reciprocators. Developmental Science, 16, 952-958. [in English].

Engelmann,_J. M., Herrmann, E., \& Tomasello, M. (2018). Concern for Group Reputation Increases Prosociality in Young Children. Psychological Science. 29 (2), 181-190. Retrieved from https://journals.sagepub.com/doi/abs/10.1177/ 0956797617733830. [in English].

Engelmann, J. M., \& Rapp, D. J. (2018). The influence of reputational concerns on children's prosociality. Current Opinion in Psychology. 20, 92-95. Retrieved from http://dx.doi.org/10.1016/j.copsyc.2017.08.024. [in English].

Fehr, E. (2004). Human behaviour: don't lose your reputation. Nature, 432, 449-450. [in English]. 
Kelsey, C., Grossmann, T., \& Amrisha, V. (2018). Early Reputation Management: Three-Year-Old Children Are More Generous Following Exposure to Eyes Front Psychol, 9, 698. Retrieved from doi: 10.3389/fpsyg.2018.00698. [in English].

Leimgruber, K. L., Shaw, A., Santos, L. R., \& Olson, K. R. (2012). Young Children Are More Generous when Others Are Aware of Their Actions. PLoS ONE, 7 (10). [in English].

Shaw, A., Montinari, N., Piovesan, M., Olson, K. R., Gino, F., \& Norton, M. I. (2014). Children develop a veil of fairness. Journal of Experimental Psychology: General, 143, 363-375. Retrieved from http://dx.doi.org/10.1037/ a0031247. [in English].

Wentzel, K. R., Filisetti, L., \& Looney, L. (2007). Adolescent prosocial behavior: The role of selfprocesses and contextual cues. Child. Develop, 78 (3), 895-910. [in English].

Whitehous, H., Jong, J., \& Buhrmester, M. D. (2017). The evolution of extreme cooperation via shared dysphoric experiences Sci. Rep. 7. Retrieved from https://www.ncbi.nlm.nih.gov/pmc/articles/PMC5349572/. [in English].

\section{GROUP REPUTATION AS A MOTIVE OF CHILDREN'S PROSOCIALITY}

Natalia Korchakova

Doctor of psychological sciences, professor, Department of Life-span and Pedagogical Psychology Rivne State University of the Humanities

ORCID iD:0000-0003-1164-3370

DOI https://doi.org/10.35619/prap_rv.vi13.122

Abstract. The issue of the emergence and development of strategically motivated prosocial behavior in childhood is discussed in the article. In general, we consider prosocial behavior as a system of experiences and actions aimed at benefits the other people or whole group. This phenomenon has many varieties: helping, gifting, equitable sharing of resources, compassion and empathy, psychological support, defending, etc. The ultimate goal of these behavioral strategies is to meet the needs of other people according to their interests, intentions and states. However, people can implement a humanistic idea on the basis of different personal motives. Their modality is within the broad dichotomous series of "altruism - selfishness". A socially valuable act may be driven by certain self-serving goals related to the future benefits. Strategically-motivated prosocial behavior is one of these types of promotion. The previous research distinguished three basic motives which underlie strategically-motivated prosocial behavior: motives of reciprocity, reputation and self-presentation. The last two motives are associated with the person's desire for social recognition and affirmation of self-importance.

Reputational motivation of prosocial behavior has recently emerged into an independent area of research. We can distinguish two interrelated issues within the mentioned problem: the influence of individual reputation vs group's reputation on prosocial behavior. Each of these issues associated not only with the mature strategies, but also with the ontogenetically early manifestations of these forms of behavior. The present study analyzes the age-related features of preschoolers' understanding and using a motive of group's reputation in situations with a potential prosocial context. It is noted that older preschoolers are able not only to carry out a system of actions, aimed at enhancing the group's reputation, but they are also concerned with monitoring and influencing the peers' behavior in order to improve performance. The obtained results of our research have shown that under condition of competition children were more concerned with the group's outcome and reputation and it had a positive effect on their prosocial behavior. Despite the self-presentational motives underlying their behavior, they supported and helped each other. In our opinion, the mutual influence of different motives of children's prosocial behavior requires further investigation.

Key words: stratedgically motivated prosocial behavior, reputation, group identification, intergroup bias, in-group. 